\title{
Teaching Reform and Practice of Physics at Application Undergraduate Colleges
}

\section{--take Baicheng Normal University as an Example}

\author{
Jide Zhang,Chunyu Xin,Lixin Che,Zhihong Zhang,Junping Xiao
}

\begin{abstract}
College of Physics and Electronic Information, Baicheng Normal University, Baicheng 137000, China
\end{abstract}

Key words: application; college physics; teaching reform and practice

\begin{abstract}
According to the urgent issues of college physics teaching in the majors of science and engineering in the application undergraduate colleges, this paper presents modular physics teaching content for different majors. Strengthening the inside class practice teaching in teaching process and adjusting the evaluation methods will be helpful to arouse students' passion and initiative, to cultivate students' independent thinking and innovation competence, and to improve the teaching effect.
\end{abstract}

\section{Introduction}

Teaching model is the urgent issue for local undergraduate colleges' transformation. In the processes of local undergraduate college education, the teaching hasn't generally extricated itself from traditional models, such as focusing on teaching materials, classrooms and teachers. Traditional cramming method is still the main teaching approach ${ }^{[1]}$. Although, the related documents issued by the education authority of the State and local government repeatedly mentions that to propose the heuristic, inquiry, discuss and participative teaching methods; to pursue the problem-based, project-based and case-based teaching and learning methods; to strengthen the integration of industry and education, work and study, post practice and school-enterprise cooperation; to reform the examination method, and focus on teaching process test and student competence assessment. But in college, because of lack of organizational and personal motivation system to promote teaching reform, traditional teaching styles and learning habits still presents inveterately in teaching process, things do not change much ${ }^{[2]}$.

College physics course is an important compulsory foundation course for students in science and engineering. The teaching of this course aims at helping students to lay a solid foundation for physics systematically, on the other hand, helping student to learn scientific method of thinking and researching problem. This course will make students to broaden their mind, inspire their exploration and innovation spirit, and strengthen their adaptive capacity ${ }^{[3-4]}$. Therefore, the physics teaching directly influences the post course study and personnel training.

In the critical period of transformation development of local colleges, physics course as a leading course, must constantly optimize teaching method and means to solve the teaching mode reform problem local college faces in transformation development.

At present, some problems exist in physics teaching which need to be resolved urgently. In order to realize the students' true feeling about physics course learning, a questionnaire survey has conducted to 284 science students from five different majors in our school, and the students investigated has learned physics course. Meanwhile, according to the physics teaching situation of our school, seven teachers who is teaching or once taught physics were interviewed. At present, the outstanding problems of physics teaching in our school are:

Fist, a unified teaching content couldn’t link up to students' major. As a foundation course of each major, the teachers place too much emphasis on its systematicness and fundamentality. Different majors take the uniform teaching programme and the same teaching standards. For years, crystallized teaching mode and bad connection between professional courses let students feel boring 
about physics learning and lack interest in learning. As time passes, a wrong understanding formed in their mind that college physics is not helpful for professional knowledge learning.

Second, less teaching class hours and a lot of contents. When revising the training plan, each major tries to increase the hours of specialized courses, which lead to the hour compression of nonprofessional courses such as college physics and laboratory course. In order to complete the teaching task of syllabus, the teachers just could repeat what the book says and fail to extend the connection among physics knowledge point, real life and specialty direction. This is the reason why students feel boring about physics learning, and the applicability of knowledge cannot be embodied.

Third, the course assessment structure is unitary. The examination of the course includes two parts: ordinary achievement and final examination. The ordinary achievement is graded by students' attendances, and the final examination is graded by examination papers. And it cannot reflect the teaching efficiency of college physics objectively and actually, let alone motivate students' study initiative.

Fourth, the teaching method is monotone. The teaching methods of the majority physics teachers are still traditional, they generally use the way of depiction teaching with combination of board writing and PPT. Teacher is the transfer of knowledge as a leading actor, and student became passive information receivers as a supporting actor, which led students lack initiative and interest in physics learning.

\section{Reform measures of college physics teaching}

\subsection{Reform of teaching content}

At the beginning of teaching content reform of college physics, we at first analyzed the training programs of each major and talked with the main subject teachers, to know the requirements of each major and realize the subject intersectional field, then carded the knowledge in physics textbook, adjusted the teaching contents on the request of different majors. To cut the class hours of chapters which less associated with each major, and add the class hours of chapters which tight associated with each major. Teachers highlight the important points according to different major, and raise students' interest in physics by their thirst for professional knowledge. In our school, science and engineering major's demand for college physics knowledges focuses on: (1). Civil engineering majors with high demands for knowledges of mechanics, thermotics and mechanical vibration (mechanical wave); (2). Machinery majors with high demands for knowledges of mechanics, electrics and magnetics; (3). Electronic information majors with high demands for electrics, magnetics and optics. On the premise of ensuring the basic needs of college physics teaching, according to the different emphasis points of the three majors, we adjust the teaching content of different majors and revise the syllabus. Meanwhile, to distinguish the depth and teaching method of the same knowledge points of different majors, with special emphasis on the knowledge points which associated with each major tightly.

\subsection{Reform of teaching method}

Combined with the requirements of applied talents' ability training, we advocate the teaching reform of college physics step by step, to establish the learner-centered teaching method, take heuristic, cooperative and participatory teaching method for the mainstream. We insist to the teaching method which arouses the students' interest in studies, and introduce inside class practice teaching in the course of teaching. For different majors, teacher distills the subjects which have applicative value in practice and associated with the professional knowledges tightly in the meantime. Such as: to mention space technology when teaching circling motion, to mention electrostatic screening principle application when teaching conductor in static electric field, to mention magnetic suspension technique when teaching Ampere force, to mention application of measuring technique when teaching diffraction of light and so on. Teacher divides the class members into several inside class practice groups and requires them to take outside class survey with the knowledge associated with the inside class practice subjects in groups, and then finish a report with the physics and specialized knowledges learned in college physics course, to elaborate the specific application of the specialized knowledges related to these practice subjects. At last, 
teacher organize students to discuss and summarize. According to outside class survey and inside class discussion, inside class practice can arouse the students' interest in college physics, cultivate their survey, analysis and summary skills, in the meantime, arouse their creative ability, which benefit students a great deal.

\subsection{Reform of evaluation mode}

Courses evaluation is an important link of teaching, and is also the key factor affecting teaching quality. The traditional evaluation mode of college physics course in our school is focus on final examination. The final grade consists of two parts: ordinary achievement (30 percent) and final examination (70 present and even more) which disadvantage is emphasize the result and overlook the process. It is difficult to improve students' motivation. Aiming at the disadvantage of current evaluation mode, we reform the exam method, pay more attention to learning process examination and students' capability evaluation. To add learning and evaluation links such as: class attendance, mid-term examination, quiz, extra-class work, investigation report (essay) and so on. These evaluations will be graded and added to the total score of final evaluation. We propose that the two parts of final grade are weighted equally and will contribute 50 percent of the grade. In ordinary achievement, 10 percent of class performance, 30 percent of inside practice (includes theory course and laboratory course), 10 percent of extra-class work, and the numbers of class performance and extra-class work are not less than three times, the numbers of inside class practice are not less than two add three times. Ordinary achievement and final examination, no matter which one is failed for a student, his overall score is failed. We increase the grade evaluation of inside class practice properly. It is beneficial to motivate students to be active in college physics study, to deepen students' understanding of physics knowledges, to increase students' awareness of the relationship between college physics and their major, and to curb the phenomena of discipline violations of college students in tests, such as to review the course just before examinations to cope with examinations and cheat in examinations. Reform of evaluation content and mode is to strengthen the control of students' learning process, to make sure the students have enough energy and enough time to learn college physics.

\section{Conclusion}

Reform of college physics teaching cannot be accomplished overnight. As explorers of teaching reform, we should research and analyze teaching practice deeply with a matter-of-fact attitude, grasp the actual situation of students' practice and our respective school's teaching model and make reasonable and effective measures, to solve the problems local undergraduate college faces in teaching model reform at present.

\section{Acknowledgements}

We would like to thank financial support of the Science Education and Planning Issues for Jinlin province (No.GH150486).

\section{References}

[1] Zhang zeping. Thought about Reform of Applied Talents in Applied Undergraduate Colleges. China Higher Education Research, 2011 (4), p55-57.

[2] Gu Yongan. Development Theory of New Undergraduate Colleges Transformation [M]. China Social Sciences Press, 2012.

[3] Li Hongrong, Wang Xiaoli, Tian Pengbo. The Teaching Reform of College Physics for Innovation Talents Training [J]. China College Teaching, 2013 (8), p19-21. 
[4] Zhang $\mathrm{Ru}, \mathrm{Wu}$ Gaojian. Reform Practice and Explore of College Physics Teaching in Technological University Based on Flipped Class Model [J]. Times Education, 2014 (21), p200201. 